\title{
Life Cycle Environmental Performance and Improvement of a Yogurt Product Delivery System
}

\author{
By Gregory A. Keoleian,* Alan W. Phipps, Tad Dritz, Dov Brachfeld
}

Center for Sustainable Systems, School of Natural Resources and Environment, University of Michigan, 430 E. University, Dana Bldg, Ann Arbor, Michigan 48 I09-I I I5, USA

A life cycle assessment was conducted to evaluate the environmental performance of the yogurt product delivery system used by Stonyfield Farm. A life cycle model was developed which included material production, manufacturing and disposition for primary and secondary packaging, as well as the related transportation links between these stages and filling, retail and the point of consumption. Product delivery systems (PDS) that utilized 4, 6, 8 and 32 oz polypropylene (PP) cups and 2 oz linear low-density polyethylene (LLDPE) tubes were analysed. Ten strategies for improving the environmental performance of these systems were proposed and their impacts on the total life cycle burden were analysed. The life cycle energy consumption for the 2, 4, 6, 8 and 32 oz containers was 4050, 4670, 5230, 4390 and $3620 \mathrm{MJ} / 1000 \mathrm{lb}$ yogurt delivered to market, respectively. Material production of the primary packaging accounted for $58 \%$ of the life cycle energy, while Distribution 3 (yogurt delivery to distributors/retailers) alone accounted for one-third of the life cycle total energy. The life cycle solid waste profile showed that as the container size decreased, the solid waste burden increased, from $27.3 \mathrm{~kg}$ (32 oz) to $42.8 \mathrm{~kg}(6 \mathrm{oz})$ per $1000 \mathrm{lb}$ yogurt delivered to market. This relationship was even more pronounced for the $4 \mathrm{oz}(47.5 \mathrm{~kg})$ and $2 \mathrm{oz}(56.2 \mathrm{~kg})$ product delivery systems. The greatest potential improvements in the environmental performance of the PDS are achievable through redesigning the primary packaging and using alternative manufacturing techniques for the yogurt cups. Shifting from injection moulding to thermoforming of $32 \mathrm{oz}$ container reduces the life cycle energy and solid waste by $18.6 \%$ and $19.5 \%$, respectively, primarily due to light-weighting. Elimination of lids for $6 \mathrm{oz}$ and $8 \mathrm{oz}$ containers provided similar benefits. Consumers purchasing yogurt in $32 \mathrm{oz}$ instead of $6 \mathrm{oz}$ containers can save $14.5 \%$ of the life cycle energy and decrease solid waste by $27.2 \%$. Copyright () 2004 John Wiley E Sons, Ltd.

Accepted 30 January 2004

KEY WORDS: life cycle assessment; yogurt packaging; energy; solid waste; greenhouse gas emissions

\footnotetext{
* Correspondence to: G. A. Keoleian, Center for Sustainable Systems, School of Natural Resources and Environment, University of Michigan, 430 E. University, Dana Bldg, Ann Arbor, Michigan 48109-1115, USA

E-mail: gregak@umich.edu

Contract/grant sponsor: Stonyfield Farm Inc., USA

Contract/grant sponsor: Polytainers Inc., Canada
} 


\section{INTRODUCTION}

Over the past two decades, the most common material used for yogurt containers has changed from coated paper to high-density polyethylene (HDPE) and then to polypropylene (PP). These changes have frustrated some consumers, as they believe that the manufacturers are moving progressively towards packaging with higher environmental burdens. Consumers question why manufacturers would switch from a \#2 plastic (HDPE), a material that is recycled in many communities, to a \#5 plastic (PP), which is collected for recycling in only a few municipalities. However, the public's perception of this problem is incorrect for two reasons: they have a misunderstanding regarding the recyclability of yogurt containers; and they are using recyclability as the sole environmental performance measure. While both PP and HDPE yogurt containes are recyclable from a technical standpoint, currently in the USA very few recycling programmes accept either PP or HDPE yogurt containers. The HDPE containers that are recycled are bottles that are made from blow-moulding grade HDPE, a material that has a different melt temperature than the HDPE used in yogurt containers.

Environmental improvement of packaging remains a key challenge facing industry. In the USA, containers and packaging accounted for $33.1 \%$ of the municipal solid waste (MSW) generated in 1999. ${ }^{1}$ While the need to reduce the solid waste from packaging is clear, opportunities for significantly reducing environmental burdens throughout the full life cycle of the product delivery system are overlooked by considering only the waste management stage of a yogurt container. Focusing packaging design improvement to endof-life issues represents a limited approach that does not account for the complex set of interrelated factors that determine environmental performance. Life cycle assessment (LCA) represents a more comprehensive method for evaluating the environmental performance of packaging systems.

LCA is an analytical tool for quantifying the material and energy inputs and outputs of the product system, assessing their potential impacts, and identifying opportunities for improvement. ${ }^{2-4}$ To support LCAs of packaging systems, the Swiss Federal Office of Environment, Forests and Landscape developed a life cycle database of common packaging materials, including aluminium, glass, paper, steel and various plastic resins. ${ }^{5,6}$ Packaging systems have been investigated for a variety of food products, including milk, ${ }^{7-10}$ juice, ${ }^{10,11}$ carbonated beverages, ${ }^{12}$ coffee, ${ }^{13}$ and ketchup. ${ }^{14}$ A wide range of life cycle studies have been conducted, comparing alternative consumer product packaging systems in terms of their environmental performance. Previous investigations made comparative assessments of alternative systems (e.g. milk in flexible pouches and returnable polycarbonate and HDPE bottles, single-use HDPE, glass and paperboard gable top containers ${ }^{10}$ ), while relatively few studies examined opportunities for improvement of individual systems (e.g. reducing the life cycle burdens of Tetra Brik milk packaging $^{9}$ ).

This paper compares a variety of yogurt container sizes and configurations and explores a range of strategies for improving the current product delivery system (PDS). A life cycle model of the current PDS used by Stonyfield Farm was constructed based on primary data collected from its New Hampshire facility, the yogurt container manufacturer Polytainers, and other firms in the supply chain. These data were supplemented with published life cycle data for materials production, energy and transportation. The specific objectives of this study were to: (a) evaluate the life cycle energy, solid waste, air pollutant emissions, water pollutant emissions and global warming potential of Stonyfield Farm's PDS; (b) understand how these environmental burdens are distributed across the product delivery system components and life cycle phases; and (c) investigate packaging design, logistics, consumer options and end-of-life management strategies to improve the system's environmental performance.

\section{METHODS}

This study applies the International Standards Organization LCA methodology (ISO 14040) to quantify the environmental burdens associated with a yogurt product delivery system. ${ }^{2}$ A life cycle model was constructed using spreadsheet software, which incorporated data from 21 primary sources with more than 8000 data inputs. This model was then used to evaluate 10 strategies for 
Table I. Primary packaging component weights and materials

\begin{tabular}{|c|c|c|c|c|c|c|}
\hline $\begin{array}{l}\text { Container } \\
\text { size }\end{array}$ & Component & Material & $\begin{array}{l}\text { Weight of } \\
\text { component } \\
\text { (g) }\end{array}$ & $\begin{array}{l}\text { Components } \\
\text { per functional } \\
\text { unit }\end{array}$ & $\begin{array}{l}\text { Component } \\
\text { weight per } \\
\text { functional unit } \\
\text { (g) }\end{array}$ & $\begin{array}{l}\text { Primary packaging } \\
\text { weight per } \\
\text { functional unit } \\
\text { (g) }\end{array}$ \\
\hline \multirow[t]{2}{*}{$2 o z$} & Tube' & LLDPE/PET & 1.40 & 8000 & I I 280 & \multirow[t]{2}{*}{48580} \\
\hline & Carton $^{2}$ & Paperboard & 37.30 & 1000 & 37300 & \\
\hline $4 o z$ & Cup & $\mathrm{PP}$ & 4.90 & 4000 & 19600 & 35680 \\
\hline \multirow[t]{3}{*}{$6 o z$} & Cup & PP & 7.80 & 2667 & 20800 & \multirow[t]{3}{*}{32080} \\
\hline & Lid & LLDPE & 3.90 & 2667 & 10400 & \\
\hline & Seal & PE/PET & 0.33 & 2667 & 880 & \\
\hline \multirow[t]{2}{*}{$8 o z$} & Cup & PP & 9.10 & 2000 & 18200 & \multirow[t]{2}{*}{26660} \\
\hline & Lid & LLDPE & 3.90 & 2000 & 7800 & \\
\hline
\end{tabular}

environmental improvement of the yogurt product delivery system. This paper presents an overview of the model while a detailed description of the methods, model parameters and data are provided elsewhere. $^{15}$

\section{Description of product delivery system}

The yogurt product delivery system (PDS) was defined as the system employed for the distribution of Stonyfield Farm's yogurt product line to market (distributor or retailer), consisting of primary packaging, secondary packaging and all transportation links required to deliver the materials, packaging, and yogurt products between the system model components. According to ISO $14040,{ }^{2}$ the functional unit of an LCA quantifies the performance of the system and provides a common reference to measuring inputs and outputs. For this system, the functional unit was defined as the product delivery system utilized for the delivery of $1000 \mathrm{lb}$ yogurt to market (distributor/retailer). The PDS analysed in this study was used by Stonyfield Farm through 2002, after which several recommendations from this study were incorporated. These improvements are highlighted in the Conclusions.

The primary packaging was defined as the yogurt packaging as it appears on retailer shelves. The primary packaging for the 6,8 and $32 \mathrm{oz}$ container sizes consisted of a PP cup, a LLDPE lid and a PE/polyester seal. The $4 \mathrm{oz}$ containers utilized a $\mathrm{PP}$ cup and PE/polyester seal and were sold in a six-pack configuration, encased by a paperboard wrap. The $2 \mathrm{oz}$ serving size was sold in squeezable LLDPE tubes that were packaged in paperboard cartons containing eight tubes. The container sizes, component weights, and materials are listed in Table 1 above.

The secondary packaging was defined as the additional packaging used during the transport of the empty containers to the yogurt filling facility, and during the delivery of the yogurt-filled containers to market. Accordingly, secondary packaging consisted of all other material used during transportation, including pallets, shrinkwrap, corrugated boxes and box liners. The secondary packaging component weights and materials are listed in Table 2 below.

A system model was developed to represent the life cycle of the product delivery system. This 


\begin{tabular}{|c|c|c|c|c|c|c|c|}
\hline \multirow[b]{2}{*}{$\begin{array}{l}\text { Product } \\
\text { line }\end{array}$} & \multicolumn{6}{|c|}{ Table 2. Secondary packaging' component weights and materials } & \multirow[b]{2}{*}{$\begin{array}{c}\text { Secondary } \\
\text { packaging } \\
\text { weight per } \\
\text { functional } \\
\text { unit } \\
\text { (g) }\end{array}$} \\
\hline & $\begin{array}{l}\text { Secondary } \\
\text { packaging } \\
\text { component }\end{array}$ & Material & Units/package & $\begin{array}{l}\text { Weight } \\
\text { (g) }\end{array}$ & $\begin{array}{l}\text { Components } \\
\text { per functional } \\
\text { unit }\end{array}$ & $\begin{array}{l}\text { Component } \\
\text { weight per } \\
\text { functional } \\
\text { unit } \\
\text { (g) }\end{array}$ & \\
\hline \multirow[t]{3}{*}{$2 o z$} & Box & Corrugated & 96 & 243 & 83.33 & 20250 & \multirow[t]{3}{*}{21484} \\
\hline & Pallet & Wood & 119808 & $18 \mid 44$ & 0.07 & 1212 & \\
\hline & Stretch wrap & LLDPE & 119808 & 331 & 0.07 & 22 & \\
\hline \multirow[t]{3}{*}{$4 \circ \mathrm{oz}$} & Box & Corrugated & 24 & 158 & 166.67 & 26333 & \multirow[t]{3}{*}{41729} \\
\hline & Pallet & Wood & 4800 & $18 \mid 44$ & 0.83 & $15 \mid 20$ & \\
\hline & Stretch wrap & LLDPE & 4800 & 331 & 0.83 & 276 & \\
\hline \multirow[t]{3}{*}{$6 o z$} & Box & Corrugated & 12 & 132 & 222.25 & 29337 & \multirow[t]{3}{*}{44002} \\
\hline & Pallet & Wood & 3360 & 18144 & 0.79 & 14402 & \\
\hline & Stretch wrap & LLDPE & 3360 & 331 & 0.79 & 263 & \\
\hline \multirow[t]{3}{*}{$8 \circ \mathrm{oz}$} & Box & Corrugated & 12 & 137 & 166.67 & 22833 & \multirow[t]{3}{*}{41162} \\
\hline & Pallet & Wood & 2016 & $18 \mid 44$ & 0.99 & 18000 & \\
\hline & Stretch wrap & LLDPE & 2016 & 331 & 0.99 & 328 & \\
\hline \multirow[t]{3}{*}{$32 \mathrm{oz}$} & Box & Corrugated & 6 & 188 & 83.33 & 15667 & \multirow[t]{3}{*}{27510} \\
\hline & Pallet & Wood & 780 & 18144 & 0.64 & 11631 & \\
\hline & Stretch wrap & LLDPE & 780 & 331 & 0.64 & 212 & \\
\hline
\end{tabular}

model, shown in Figure 1, is organized into nine process units - material production, distribution 1 , manufacturing, distribution 2, filling, distribution 3 , distributors/retailers, yogurt consumption and end-of-life.

A life cycle inventory was performed to evaluate the material and energy resources consumed, as well as environmental emissions and waste generated throughout the system. The life cycle inventory analysis involved data collection and calculation procedures to quantify relevant inputs and outputs that occur during each unit process within the system. ${ }^{\dagger}$ Inputs and outputs associated with each unit process were quantified through primary data collection for the year 1999, and using parameters from published LCA data. ${ }^{16}$ The model was developed to evaluate the environmental burdens for a North American product delivery system; however, much of the data for

\footnotetext{
${ }^{+}$The application of allocation principles and procedures of this study as well as additional elaboration required for recycling and reuse situations is explained in detail in the original study report. The procedures for data collection and sources of the data are also provided in detail to ensure transparency.
}

packaging materials production burdens came from European sources, due to a lack of published US data. Production processes are expected to be similar but environmental emissions for these processes will vary between countries and also among plants within a given country. The emissions and energy consumed at each process unit were calculated based on the model parameters of the various packaging configurations. The model parameters included the weight, composition and manufacturing process for both the primary and secondary packaging along with the transport distances and modes of transport associated with each unit process. The transport distances and modes of transport for the primary packaging and secondary packaging components are detailed in Tables 3 and 4, respectively.

This life cycle assessment was conducted to characterize the magnitude and significance of the potential environmental impacts of the system. In the life cycle inventory analysis, inputs and outputs associated with each unit process were quantified using the following data categories: energy consumption, solid waste generation, air 


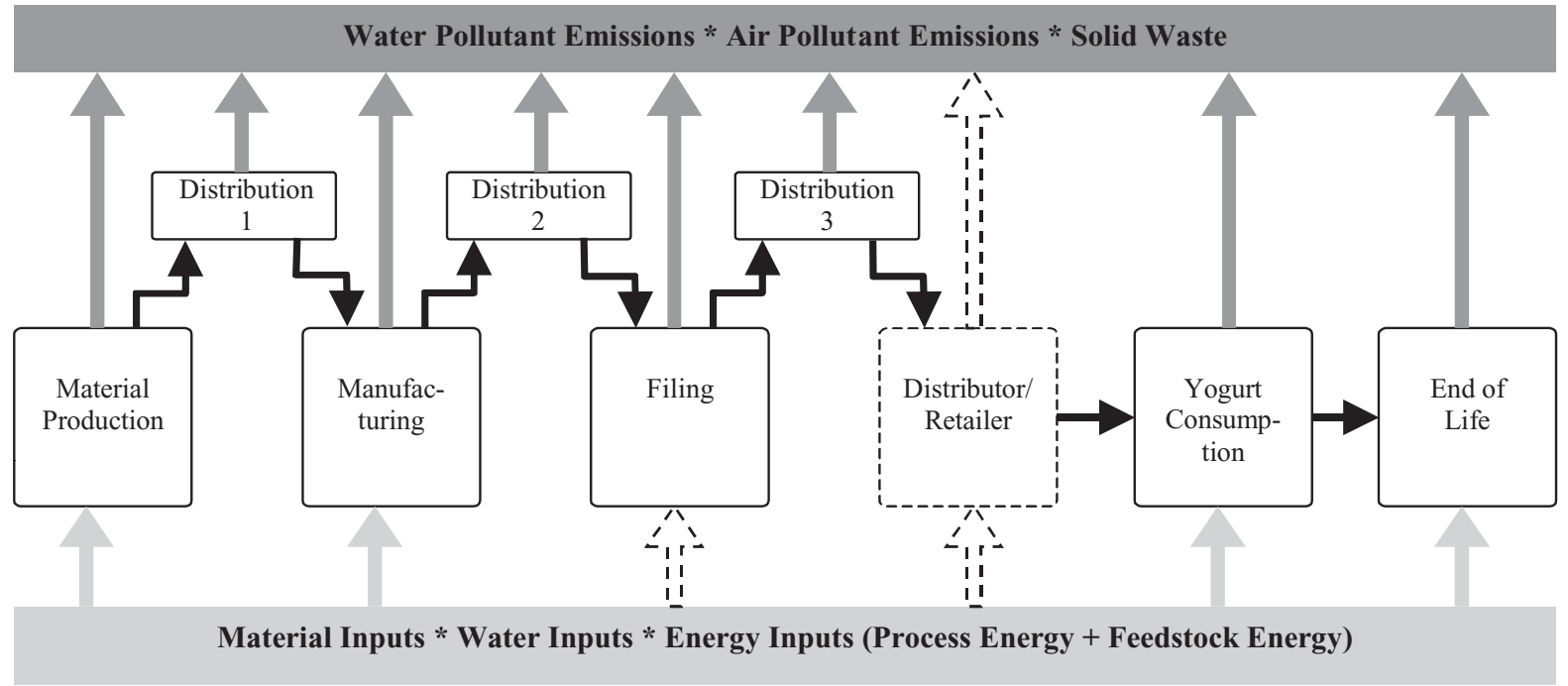

Key:

Flow of PDS through life cycle
Flow of Material, Water and Energy Inputs
Flow of Water Pollution Emissions, Air Pollution Emissions and Solid Waste
----- Outside of the system boundary

Figure I. Overview of system model.

Table 3. Transport distances for primary packaging materials and components

\begin{tabular}{|c|c|c|c|c|c|}
\hline \multirow[b]{2}{*}{ Phase } & \multirow[b]{2}{*}{ Component } & \multirow{2}{*}{$\begin{array}{l}\text { Distance } \\
\text { (miles) }\end{array}$} & \multicolumn{2}{|c|}{ Mode' (\%) } & \multirow{2}{*}{$\begin{array}{l}\text { Data } \\
\text { source }\end{array}$} \\
\hline & & & Truck & Rail & \\
\hline \multirow[t]{8}{*}{ Distribution I } & PP resin for cups & 425 & 1 & 99 & Supplier \\
\hline & Colour concentrate for cups and lids & 90 & 100 & 0 & Supplier \\
\hline & Paperboard for wraps and cartons & 406 & 100 & 0 & Supplier \\
\hline & $P E$ and $P E T$ resins for seals & 492 & 100 & 0 & Supplier \\
\hline & LLDPE resin for lids & 190 & 8 & 92 & Supplier \\
\hline & LLDPE and PET resins for tubes & 1100 & 0 & 100 & Supplier \\
\hline & Adhesive for tubes & 800 & 100 & 0 & Supplier \\
\hline & Colour concentrate for tubes & 1100 & 0 & 100 & Supplier \\
\hline \multirow[t]{6}{*}{ Distribution 2} & Cups & 587 & 100 & 0 & Supplier \\
\hline & Lids & 587 & 100 & 0 & Supplier \\
\hline & Seals & 1050 & 100 & 0 & Supplier \\
\hline & Wraps & 694 & 100 & 0 & Supplier \\
\hline & Tubes & 1194 & 100 & 0 & Supplier \\
\hline & Cartons & 694 & 100 & 0 & Supplier \\
\hline Distribution 3 & Yogurt and primary packaging & 552 & 100 & 0 & Estimate $^{\prime}$ \\
\hline
\end{tabular}




\section{and Science}

Table 4. Transport distances for secondary packaging materials and components

\begin{tabular}{|c|c|c|c|c|}
\hline Phase & Component & $\begin{array}{l}\text { Distance } \\
\text { (miles) }\end{array}$ & Mode' & Data source \\
\hline Distribution 3 & $\begin{array}{l}\text { Box for cup and lid } \\
\text { Liner and sleeve for cup and lid } \\
\text { Pallet for cup and lid } \\
\text { Box for wrap } \\
\text { Pallet for wrap } \\
\text { Stretch wrap for wrap } \\
\text { Divider for wrap } \\
\text { Stretch wrap for cup and lid } \\
\text { Core tube for seal and tube } \\
\text { Pallet for seal, tube and carton } \\
\text { Stretch wrap for seal, tube and carton } \\
\text { Slip sheet for seal } \\
\text { Roll wrap for seal } \\
\text { Case for tube and carton } \\
\text { End cap for tube } \\
\text { Spool for tube } \\
\text { Box } \\
\text { Pallet } \\
\text { Stretch wrap }\end{array}$ & $\begin{array}{c}5 \\
9.4 \\
23 \\
380 \\
20 \\
20 \\
180 \\
18 \\
77 \\
77 \\
77 \\
77 \\
77 \\
77 \\
77 \\
77 \\
48 \\
10 \\
138\end{array}$ & $\begin{array}{l}100 \% \text { truck } \\
100 \% \text { truck } \\
100 \% \text { truck } \\
100 \% \text { truck } \\
100 \% \text { truck } \\
100 \% \text { truck } \\
100 \% \text { truck } \\
100 \% \text { truck } \\
100 \% \text { truck } \\
100 \% \text { truck } \\
100 \% \text { truck } \\
100 \% \text { truck } \\
100 \% \text { truck } \\
100 \% \text { truck } \\
100 \% \text { truck } \\
100 \% \text { truck } \\
100 \% \text { truck } \\
100 \% \text { truck } \\
100 \% \text { truck }\end{array}$ & $\begin{array}{l}\text { Supplier } \\
\text { Supplier } \\
\text { Supplier } \\
\text { Supplier } \\
\text { Supplier } \\
\text { Supplier } \\
\text { Supplier } \\
\text { Supplier } \\
\text { Estimate } \\
\text { Estimate } \\
\text { Estimate } \\
\text { Estimate } \\
\text { Estimate } \\
\text { Estimate } \\
\text { Estimate } \\
\text { Estimate } \\
\text { Supplier } \\
\text { Supplier } \\
\text { Supplier }\end{array}$ \\
\hline
\end{tabular}

emissions, water emissions and water use. The air pollutant emissions and water pollution effluents are listed in Tables 5 and 6, respectively. The life cycle impact assessment was limited to two impact categories: global warming potential (GWP) and ozone depletion potential (ODP).

\section{System boundaries}

Material production. The material production phase includes the extraction of the raw materials, as well as the materials manufacture, which is the processing of the raw materials into intermediate materials, for the primary packaging. Material production of secondary packaging is included in the distribution phases. The environmental burdens associated with material production of PP, LLDPE, HDPE, PET, PE and colour concentrate were based on European life cycle inventory data. Material production burdens for plastics made in Europe were assumed to be similar to those in North America. The material production of minor ingredients, such as adhesives, inks and additives, were excluded from the scope of this study.
Distribution I. Distribution 1 includes the transportation of primary packaging input materials (e.g. plastic resins) between material producers and the respective container component manufacturers. The burdens of fuel production and fuel use for rail and truck transport were modelled. Nearly all of the shipments in this phase utilized bulk trucks or railcars and therefore the use of nonreusable secondary packaging was very limited and consequently excluded from the inventory analysis.

Manufacturing. The manufacturing phase includes the fabrication of only the primary packaging, such as the injection-moulding of the cups and lids. Manufacturing of secondary packaging was included in the distribution phases. Burdens associated with the production of the manufacturing equipment were excluded from the system model, as they were expected to be small relative to the burdens associated with the processes that were inventoried.

Distribution 2. Distribution 2 includes the transportation of the primary packaging materials from 
Table 5. Air pollutant emissions

Acenaphthene $\left(\mathrm{C}_{12} \mathrm{H}_{10}\right)$

Acenaphthylene $\left(\mathrm{C}_{12} \mathrm{H}_{8}\right)$

Acetaldehyde $\left(\mathrm{CH}_{3} \mathrm{CHO}\right)$

Acetophenone $\left(\mathrm{C}_{8} \mathrm{H}_{8} \mathrm{O}\right)$

Acrolein $\left(\mathrm{CH}_{2} \mathrm{CHCHO}\right)$

Aldehyde (unspecified)

Aluminium (Al)

Ammonia $\left(\mathrm{NH}_{3}\right)$

Anthracene $\left(\mathrm{C}_{14} \mathrm{H}_{10}\right)$

Antimony (Sb)

Aromatic hydrocarbons (unspecified)

Arsenic (As)

Barium (Ba)

Benzene $\left(\mathrm{C}_{6} \mathrm{H}_{6}\right)$

Benzo(a)anthracene

Benzo(a)pyrene $\left(\mathrm{C}_{20} \mathrm{H}_{12}\right)$

Benzo(b)fluoranthene

Benzo(bjk)fluoranthene

Benzo(ghi)perylene

Benzo(k)fluoranthene

Benzyl chloride $\left(\mathrm{C}_{7} \mathrm{H}_{7} \mathrm{Cl}\right)$

Beryllium (Be)

Bromoform $\left(\mathrm{CHBr}_{3}\right)$

Butane $\left(\mathrm{C}_{4} \mathrm{H}_{10}\right)$

Cadmium (Cd)

Calcium (Ca)

Carbon dioxide $\left(\mathrm{CO}_{2}\right.$, biomass)

Carbon dioxide $\left(\mathrm{CO}_{2}\right.$, fossil)

Carbon disulphide $\left(\mathrm{CS}_{2}\right)$

Carbon monoxide (CO)

Carbon tetrachloride $\left(\mathrm{CCl}_{4}\right)$

CFC and HCFC

Chlorides $\left(\mathrm{Cl}^{-}\right)$

Chlorinated matter (unspecified, as $\mathrm{Cl}$ )

Chlorine $\left(\mathrm{Cl}_{2}\right)$

Chloroacetophenone $\left(2-\mathrm{C}_{8} \mathrm{H}_{7} \mathrm{ClO}\right)$

Chlorobenzene $\left(\mathrm{C}_{6} \mathrm{H}_{5} \mathrm{Cl}\right)$

Chloroform $\left(\mathrm{CHCl}_{3}, \mathrm{HC}-20\right)$

Chromium ( $\mathrm{Cr}$ III, $\mathrm{Cr}$ VI)

Chrysene $\left(\mathrm{C}_{18} \mathrm{H}_{12}\right)$

Cobalt (Co)

Copper (Cu)

Cumene $\left(\mathrm{C}_{9} \mathrm{H}_{12}\right)$

Cyanide $\left(\mathrm{CN}^{-}\right)$

$\mathrm{Di}\left(2\right.$-ethylhexyl)phthalate (DEHP, $\mathrm{C}_{24} \mathrm{H}_{38} \mathrm{O}_{4}$ )

Dibenzo(a,h)anthracene

Dichlorobenzene $\left(\mathrm{I}, 4-\mathrm{C}_{6} \mathrm{H}_{4} \mathrm{Cl}_{2}\right)$

Dimethyl benzanthracene $\left(7,12-\mathrm{C}_{20} \mathrm{H}_{16}\right)$

Dimethyl sulphate $\left(\mathrm{C}_{2} \mathrm{H}_{6} \mathrm{O}_{4} \mathrm{~S}\right)$

Dinitrotoluene $\left(2,4-\mathrm{C}_{7} \mathrm{H}_{6} \mathrm{~N}_{2} \mathrm{O}_{4}\right)$

Dioxins (unspecified)

Diphenyl $\left(\left(\mathrm{C}_{6} \mathrm{H}_{5}\right)_{2}\right)$

Ethane $\left(\mathrm{C}_{2} \mathrm{H}_{6}\right)$

Ethyl benzene $\left(\mathrm{C}_{6} \mathrm{H}_{5} \mathrm{C}_{2} \mathrm{H}_{5}\right)$

Ethyl chloride $\left(\mathrm{C}_{2} \mathrm{H}_{5} \mathrm{Cl}\right)$

Ethylene dibromide $\left(\mathrm{C}_{2} \mathrm{H}_{4} \mathrm{Br}_{2}\right)$

Ethylene dichloride $\left(\mathrm{C}_{2} \mathrm{H}_{4} \mathrm{Cl}_{2}\right)$

Fluoranthene

Fluorene $\left(\mathrm{C}_{13} \mathrm{H}_{10}\right)$

Fluorides $\left(\mathrm{F}^{-}\right)$

Fluorine $\left(\mathrm{F}_{2}\right)$

Formaldehyde $\left(\mathrm{CH}_{2} \mathrm{O}\right)$

Furan $\left(\mathrm{C}_{4} \mathrm{H}_{4} \mathrm{O}\right)$
Halogenated hydrocarbons (unspecified)

Halogenated matter (unspecified)

Halon I30I $\left(\mathrm{CF}_{3} \mathrm{Br}\right)$

Hexane $\left(\mathrm{C}_{6} \mathrm{H}_{14}\right)$

Hydrocarbons (except methane)

Hydrocarbons (unspecified)

Hydrogen $\left(\mathrm{H}_{2}\right)$

Hydrogen chloride $(\mathrm{HCl})$

Hydrogen fluoride (HF)

Hydrogen sulphide $\left(\mathrm{H}_{2} \mathrm{~S}\right)$

Indeno $(\mathrm{I}, 2,3, \mathrm{c}, \mathrm{d})$ Pyrene

Iron (Fe)

Isophorone

Lead $(\mathrm{Pb})$

Magnesium (Mg)

Manganese (Mn)

Mercaptans

Mercury $(\mathrm{Hg})$

Metals (unspecified)

Methane $\left(\mathrm{CH}_{4}\right)$

Methyl bromide $\left(\mathrm{CH}_{3} \mathrm{Br}\right)$

Methyl chloride $\left(\mathrm{CH}_{3} \mathrm{Cl}\right)$

Methyl cholanthrene $\left(3-\mathrm{C}_{21} \mathrm{H}_{16}\right)$

Methyl chrysene $\left(5-\mathrm{C}_{19} \mathrm{H}_{15}\right)$

Methyl ethyl ketone (MEK, $\mathrm{C}_{4} \mathrm{H}_{8} \mathrm{O}$ )

Methyl hydrazine $\left(\mathrm{CH}_{6} \mathrm{~N}_{2}\right)$

Methyl methacrylate $\left(\mathrm{CH}_{2} \mathrm{C}\left(\mathrm{CH}_{3}\right) \mathrm{COOCH}_{3}\right)$

Methyl naphthalene $\left(2-\mathrm{C}_{1 \mid} \mathrm{H}_{10}\right)$

Methyl-tert-butyl ether (MTBE, $\mathrm{C}_{5} \mathrm{H}_{12} \mathrm{O}$ )

Methylene chloride $\left(\mathrm{CH}_{2} \mathrm{Cl}_{2}, \mathrm{HC}-\mathrm{I} 30\right)$

Molybdenum (Mo)

Naphthalene $\left(\mathrm{C}_{10} \mathrm{H}_{8}\right)$

Nickel (Ni)

Nitrogen oxides $\left(\mathrm{NO}_{x}\right.$ as $\left.\mathrm{NO}_{2}\right)$

Nitrous oxide $\left(\mathrm{N}_{2} \mathrm{O}\right)$

Organic matter (unspecified)

Particulates (PM I0)

Particulates (unspecified)

Pentane $\left(\mathrm{C}_{5} \mathrm{H}_{12}\right)$

Phenanthrene $\left(\mathrm{C}_{14} \mathrm{H}_{10}\right)$

Phenol $\left(\mathrm{C}_{6} \mathrm{H}_{5} \mathrm{OH}\right)$

Phosphorus (P)

Polycyclic aromatic hydrocarbons (PAH, unspecified)

Propane $\left(\mathrm{C}_{3} \mathrm{H}_{8}\right)$

Propionaldehyde $\left(\mathrm{CH}_{3} \mathrm{CH}_{2} \mathrm{CHO}\right)$

Pyrene $\left(\mathrm{C}_{16} \mathrm{H}_{10}\right)$

Selenium (Se)

Silicon (Si)

Sodium $(\mathrm{Na})$

Styrene $\left(\mathrm{C}_{6} \mathrm{H}_{5} \mathrm{CHCH}_{2}\right)$

Sulphur dioxide $\left(\mathrm{SO}_{2}\right)$

Sulphur oxides $\left(\mathrm{SO}_{\mathrm{x}}\right.$ as $\left.\mathrm{SO}_{2}\right)$

Sulphuric acid $\left(\mathrm{H}_{2} \mathrm{SO}_{4}\right)$

Tetrachloroethylene $\left(\mathrm{C}_{2} \mathrm{Cl}_{4}\right)$

Toluene $\left(\mathrm{C}_{6} \mathrm{H}_{5} \mathrm{CH}_{3}\right)$

Trichloroethane $\left(\mathrm{I}, \mathrm{I}, \mathrm{I}-\mathrm{CH}_{3} \mathrm{CCl}_{3}\right)$

Trichloroethylene $\left(\mathrm{CCl}_{2} \mathrm{CHCl}\right)$

Vanadium (V)

Vinyl acetate $\left(\mathrm{C}_{4} \mathrm{H}_{6} \mathrm{O}_{2}\right)$

Vinyl chloride $\left(\mathrm{CH}_{2} \mathrm{CHCl}\right)$

Xylene $\left(\mathrm{C}_{6} \mathrm{H}_{4}\left(\mathrm{CH}_{3}\right)_{2}\right)$

Zinc (Zn)

Radioactive substance (unspecified) 


\section{and Science}

\section{Table 6. Water pollutant effluents}

Acids $\left(\mathrm{H}^{+}\right)$

Aluminium $\left(\mathrm{Al}^{+}\right)$

Ammonia $\left(\mathrm{NH}_{4}^{+}, \mathrm{NH}_{3}\right.$, as $\left.\mathrm{N}\right)$

AOX (adsorbable organic halogens)

Aromatic hydrocarbons (unspecified)

Arsenic $\left(\mathrm{As}^{3+}, \mathrm{As}^{5+}\right)$

Barium $\left(\mathrm{Ba}^{++}\right)$

Benzene $\left(\mathrm{C}_{6} \mathrm{H}_{6}\right)$

BOD5 (biochemical oxygen demand)

Cadmium $\left(\mathrm{Cd}^{++}\right)$

Calcium $\left(\mathrm{Ca}^{++}\right)$

Carbon tetrachloride $\left(\mathrm{CCl}_{4}\right)$

Carbonates $\left(\mathrm{CO}_{3}^{--}, \mathrm{HCO}_{3}^{-}, \mathrm{CO}_{2}\right.$, as $\left.\mathrm{C}\right)$

Chlorides $\left(\mathrm{Cl}^{-}\right)$

Chlorine $\left(\mathrm{Cl}_{2}\right)$

Chlorinated matter (unspecified, as $\mathrm{Cl}$ )

Chloroform $\left(\mathrm{CHCl}_{3}, \mathrm{HC}-20\right)$

Chromium ( $\mathrm{Cr}$ III, Cr VI)

COD (chemical oxygen demand)

Copper $\left(\mathrm{Cu}^{+}, \mathrm{Cu}^{++}\right)$

Cyanide $\left(\mathrm{CN}^{-}\right)$

Dissolved matter (unspecified)

Dissolved organic carbon (DOC)

Ethyl benzene $\left(\mathrm{C}_{6} \mathrm{H}_{5} \mathrm{C}_{2} \mathrm{H}_{5}\right)$

Ethylene dichloride $\left(\mathrm{C}_{2} \mathrm{H}_{4} \mathrm{Cl}_{2}\right)$

Fluorides $\left(\mathrm{F}^{-}\right)$

Halogenated matter (organic)

Hydrocarbons (unspecified)

Inorganic dissolved matter (unspecified)

Iron $\left(\mathrm{Fe}^{++}, \mathrm{Fe}^{3+}\right)$

Lead $\left(\mathrm{Pb}^{++}, \mathrm{Pb}^{4+}\right)$

Magnesium $\left(\mathrm{Mg}^{++}\right)$

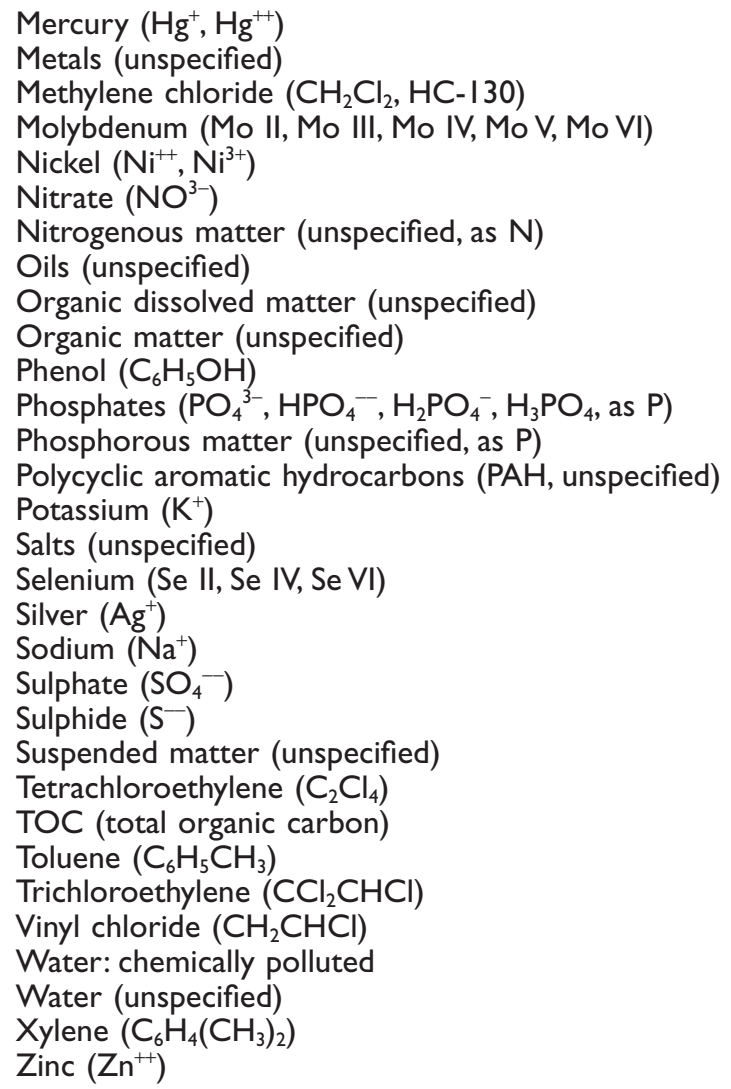

their manufacturing location to the yogurt filling facility, as well as the material production, transportation and disposal of the secondary packaging used to transport the primary packaging. The burdens of fuel production and fuel use for truck transport were modelled. The burdens associated with the converting processes for the secondary packaging, such as conversion of corrugated board into boxes or lumber into pallets, were judged to be relatively small and were therefore neglected.

Filling. The environmental burdens associated with the yogurt filling process were outside the scope of this investigation. Stonyfield Farm indicated that changes in primary packaging configuration or materials would have negligible impacts on filling burdens. The one exception was the solid waste generated from the sealing process, since it was considered to be part of the packaging system. The solid waste generated during the sealing process was a web of $\mathrm{PE} /$ polyester created when circular seals were cut out of the rolls of film.

Distribution 3. Distribution 3 includes the transportation of yogurt and its primary and secondary packaging from the filling location to the first destination, which is typically a distributor or retailer. Transport burdens for this and other distribution phases were allocated by weight. The environmental burdens associated with material production, manufacturing, transportation and end-of-life disposal of the secondary packaging used during this leg of transportation were included. As in distribution 2, the conversion of these materials into secondary packaging, such as corrugated board 
into boxes or wood into pallets, was not included in this model.

Distributor/retailer. Environmental burdens associated with activities in the distributor/retailer phase were excluded from the system model.

Consumption. The consumption phase represents activities conducted by the consumer after purchasing the yogurt products. Environmental burdens associated with the transportation of the yogurt from the retailer to the consumer were not modelled. The two activities included in this phase are refrigeration of the yogurt and the washing of bowls and spoons used by the consumer. The assumptions used to calculate the energy and water required to wash the bowls and spoons are detailed in Table 7.

The energy used by the consumer to refrigerate the yogurt was calculated assuming an average of 3 days of refrigeration, which is based on a consumer eating one serving of yogurt per day and purchasing yogurt once per week. A portion of the energy consumed by the refrigerator was allocated to the yogurt, based on the ratio of the volume that the yogurt package occupies to the usable volume in the refrigerator. The burdens including air and water emissions for the energy consumed during this life cycle stage is based on an average US power generation profile.

In the case of $4 \mathrm{oz}, 6 \mathrm{oz}$ and $8 \mathrm{oz}$ containers, the disposable PP container serves to transport and store yogurt, and it also functions as the cup or bowl from which the yogurt is eaten. However, while the $32 \mathrm{oz}$ container is also used to transport and store the yogurt, in most cases an additional bowl is used to serve the yogurt for consumption. Spoons are also used for yogurt consumption for all container sizes, with the exception of the $2 \mathrm{oz}$ tube container. The use of bowls and spoons contributes to life cycle burdens because additional water and energy is required for the washing process. Environmental burdens associated with the use of detergents and towels were not inventoried but considered relatively minor.

End-of-life. End-of-life process modelling accounted for the environmental burdens that stemmed from waste management of used primary packaging, including the transportation from the consumer to the disposal location. Note that all secondary packaging is disposed of in the phase where it was utilized. It was assumed that all of the yogurt products produced in the filling phase were consumed and all the containers were transported to waste management sites to be recycled, incinerated or landfilled. Recycle rates were determined from an EPA municipal solid waste report to be $0 \%$ for plastic wide-mouth containers and $15.8 \%$ for cardboard. ${ }^{17}$ The incineration rate was calculated using data from the same EPA report. The report stated that, of the entire municipal waste stream, $55.1 \%$ of the waste was landfilled, 28\% was recycled and $16.9 \%$ was incinerated. Using these figures, it was estimated that the average incineration rate for the municipal waste stream that remained after recycled materials were removed was $23.5 \%$. In this study, an incineration rate of $23.5 \%$ was applied to the waste that remained after recycled materials were subtracted from the total.

Table 7. Assumptions used to calculate energy and water use during consumption phase

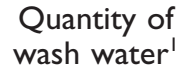

(oz)

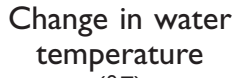

$\left({ }^{\circ} \mathrm{F}\right)$

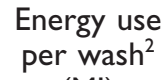

(MJ)

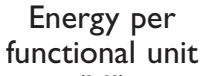

(MJ)

Water use per functional unit (gal)

0.132

0.066

264

132

375

188

Bowl ${ }^{3}$

12

50

'It is assumed that bowls and spoons are hand-washed.

${ }^{2}$ It is assumed that the water is heated using a natural gas water heater with an efficiency rating of 0.7 .

${ }^{3}$ It is assumed that four bowls are used for each $32 \mathrm{oz}$ container and other container sizes do not require bowls.

${ }^{4}$ One spoon is required per serving of yogurt for all container sizes except the $2 \mathrm{oz}$. 
The air emission and water emission data categories refer to the tracking and aggregation of total emissions to air and emissions to water at each phase of the life cycle, measured by weight. ${ }^{16}$ Life cycle water use refers to the total water use at each phase of the life cycle measured by volume. ${ }^{16}$ These totals include emissions from power generation that supplies various processes in the life cycle, including primary packaging manufacturing and consumption.

Global warming potential is the impact category measuring potential contribution of the product delivery system to the 'greenhouse effect'. The GWP index, based on the model compiled by the Intergovernmental Panel on Climate Change, is defined as the cumulative radiative effect between the present and a chosen time horizon (here 100 years is used), caused by a unit mass of emitted gas, expressed relative to that for some reference gas (IPCC and this study use $\mathrm{CO}_{2}$ ). ${ }^{18}$

Ozone depletion potential is the impact category measuring potential contribution by the product delivery system to deterioration of the stratospheric ozone layer. The most accepted ODP model, developed by the World Meteorological Organization, is employed in this study and measures ODP in equivalent $\mathrm{mg}$ CFC-11. ${ }^{19}$

\section{RESULTS}

The results of the LCA are presented in two sections. The first quantifies the burdens associated with the current product delivery system and shows how these burdens are distributed over life cycle phases and across cup sizes. The second section examines strategies for minimizing environmental burdens. The results are based on the delivery of $1000 \mathrm{lb}$ yogurt to market.

\section{Current product delivery system (PDS)}

The results of this study reinforce the general perception that larger containers have lower environmental burdens. When the overall energy requirements for the product delivery systems were compared, $32 \mathrm{oz}$ containers are preferred. The total energy consumption for $2 \mathrm{oz}, 4 \mathrm{oz}, 6 \mathrm{oz}, 8 \mathrm{oz}$ and $32 \mathrm{oz}$ were 4050, 4670, 5230, 4390 and 3620 megajoules (MJ), respectively. Significant amounts of energy are consumed at the material production and manufacturing phases, as well as in distribution 3 , the delivery of yogurt from the yogurt producer to distributors and retailers. Figure 2 shows energy demand by life cycle phase for the current PDS.

In the material production phase, the $6 \mathrm{oz}$ container showed the highest energy value due to the quantity of material needed to deliver one functional unit of yogurt and the material production energy of lids. Energy results for the $6 \mathrm{oz}, 8 \mathrm{oz}$ and $32 \mathrm{oz}$ containers demonstrate the relationship between material intensity and energy burdens. However, the $2 \mathrm{oz}$ and $4 \mathrm{oz}$ product delivery system scenarios did not adhere to the container size-energy intensity pattern, because they employ different configurations, both of which use less plastic per functional unit. The $4 \mathrm{oz}$ six-pack utilizes one coated paperboard wrap rather than six LLDPE lids, and the $2 \mathrm{oz}$ configuration uses lightweight tubes with a coated paperboard carton. The primary packaging weights of the $2 \mathrm{oz}$ and $4 \mathrm{oz}$ scenarios exceed those of the 6oz-per functional unit but have an energy advantage, due to the material production energy of coated paperboard $(25.7 \mathrm{MJ} / \mathrm{kg})$ falling below that of the LLDPE $(72.3 \mathrm{MJ} / \mathrm{kg})$ lids and PP $(74.9 \mathrm{MJ} / \mathrm{kg})$ cups.

The quantity and variety of material required for each container size PDS was also responsible for the pattern observed at the manufacturing stage. The injection-moulding of plastics was modelled assuming constant environmental burdens per mass of plastic formed. So, the plastic-intensive 6 oz PDS again had the highest energy burden. The $2 \mathrm{oz}$ and $4 \mathrm{oz}$ scenarios again departed from the pattern because the conversion process for paperboard required only $6.9 \mathrm{MJ} / \mathrm{kg}$ compared to 19.6 $\mathrm{MJ} / \mathrm{kg}$ for injection moulding.

Another notable aspect of the energy profile shown in Figure 2 was the significance of the distribution 3 phase. Figure 3 shows that the energy breakdown between secondary packaging production and transportation in the distribution from the yogurt filling facility to distributors and retailers. In this life cycle phase, a full $58 \%$ of the energy consumed is attributed to production and transportation of secondary packaging, while $40 \%$ is attributed to the transport of the yogurt product. The transport energy is defined as the energy required to physically move the various compo- 


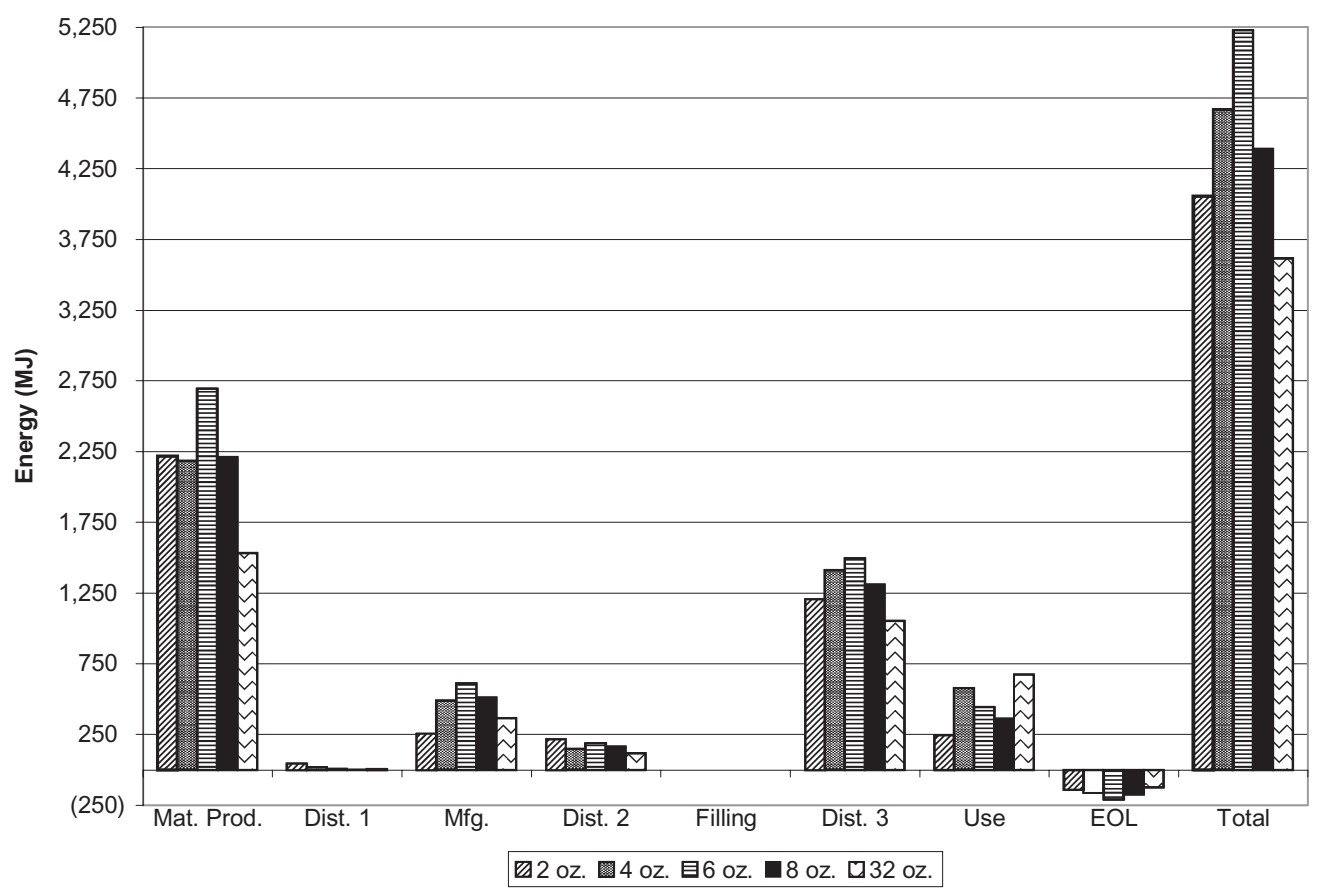

Figure 2. Current PDS life cycle energy by phase.

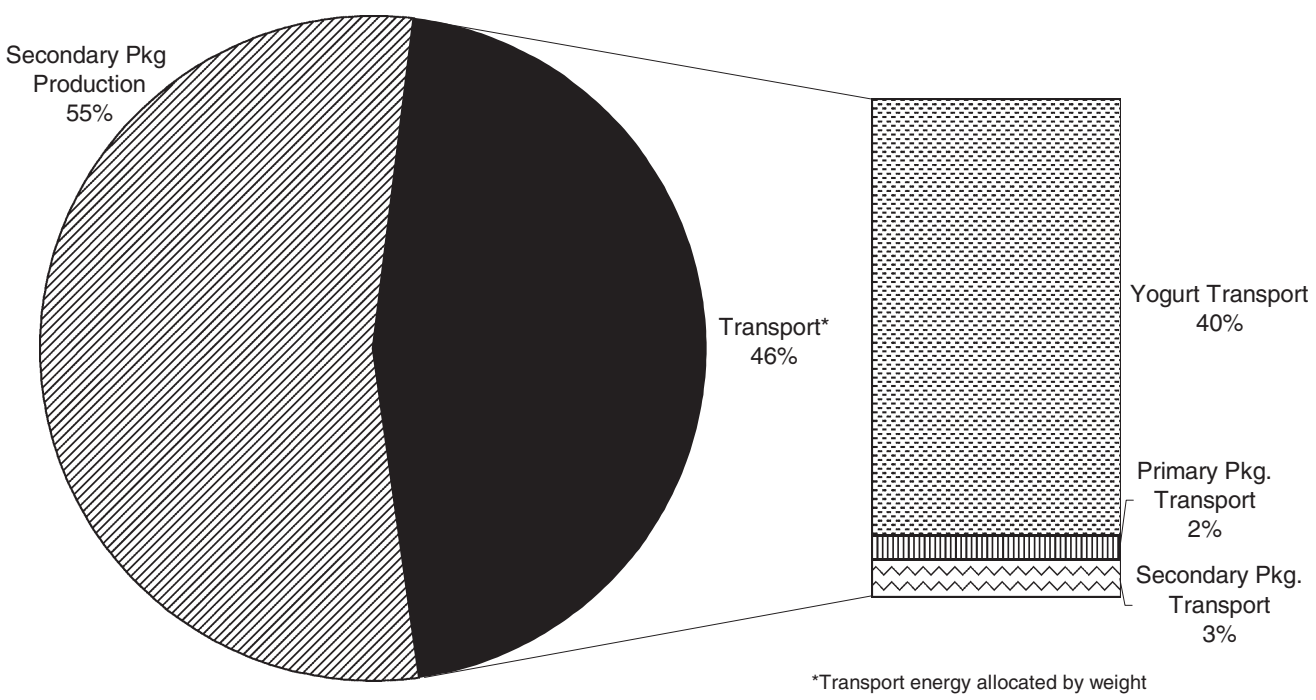

Figure 3. Current PDS distribution 3 energy.

nents (yogurt, primary and secondary packaging), allocated by weight, as well as the energy consumed in producing and generating the transportation fuel, in this case diesel.
The negative values in the end-of-life phase of Figure 2 represent an energy credit due to the electricity produced from the incineration of plastic and paperboard primary packaging materials. A 


\section{and Science}

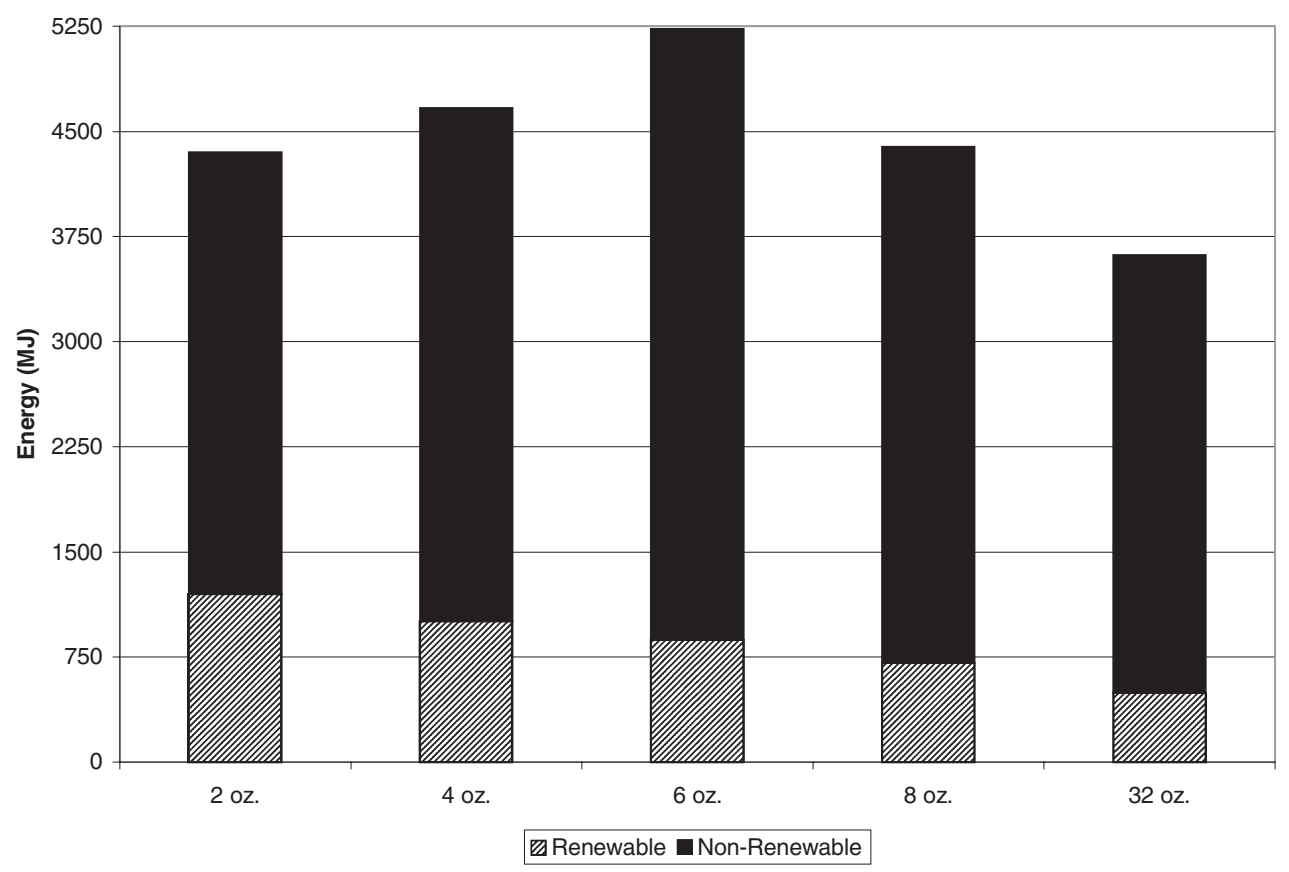

Figure 4. Current PDS energy by container size.

credit was given for the avoided pollution from grid electricity generation, using the average US electricity generation fuel mix of coal (56.6\%), natural gas $(8.6 \%)$, heavy fuel oil $(2.2 \%)$, nuclear $(22 \%)$ and hydroelectricity $(10.6 \%){ }^{16}$ The burdens from the incineration of the plastic and paperboard packaging materials were accounted for in the model.

The use of renewable and non-renewable energy was also tracked throughout the life cycle of each size container. Figure 4 shows the renewable and non-renewable energy consumption for the different size containers. This graph indicates that the $2 \mathrm{oz}$ and $4 \mathrm{oz}$ product delivery systems had the highest fraction of renewable energy, with $28 \%$ and $22 \%$, respectively, compared to $17 \%$ for $6 \mathrm{oz}, 16 \%$ for $8 \mathrm{oz}$ and $14 \%$ for $32 \mathrm{oz}$. Biomass energy used to produce coated paperboard (for the wraps and cartons) is largely responsible for the higher renewable energy content.

The life cycle solid waste profile follows the pattern that smaller containers require a greater amount of material to deliver the same quantity of product. This relationship, seen as the size decreased from $32 \mathrm{oz}(27.3 \mathrm{~kg})$ to $8 \mathrm{oz}(36.4 \mathrm{~kg})$ to 6 oz $(42.8 \mathrm{~kg})$, was even more pronounced for the 4 oz PDS (47.5 kg) and $2 \mathrm{oz}$ PDS (56.2 kg). The phases responsible for the largest solid waste burdens for the $2 \mathrm{oz}$ and $4 \mathrm{oz}$ product delivery systems were manufacturing and end-of-life. Figure 5 shows the life cycle solid waste generation of the current product delivery system by phase.

Solid waste produced at the manufacturing phase was calculated based on the mass of material and the conversion process employed. The $2 \mathrm{oz}$ and $4 \mathrm{oz}$ scenarios were penalized for both these aspects. The quantity of primary packaging material needed for a functional unit delivered in $2 \mathrm{oz}$ tubes and $4 \mathrm{oz}$ containers were $48.2 \mathrm{~kg}$ and $35.7 \mathrm{~kg}$, compared to $34.5 \mathrm{~kg}$ for $6 \mathrm{oz}$ containers. The conversion process for wraps produced $0.62 \mathrm{~kg}$ of solid waste for each $\mathrm{kg}$ of output, while injectionmoulding generated only $0.15 \mathrm{~kg} / \mathrm{kg}$ output.

The end-of-life solid waste burdens were calculated by subtracting recycled cups, lids and wraps from the total mass of primary packaging. The remaining waste stream was then landfilled or incinerated in a waste-to-energy facility at the 
and Science

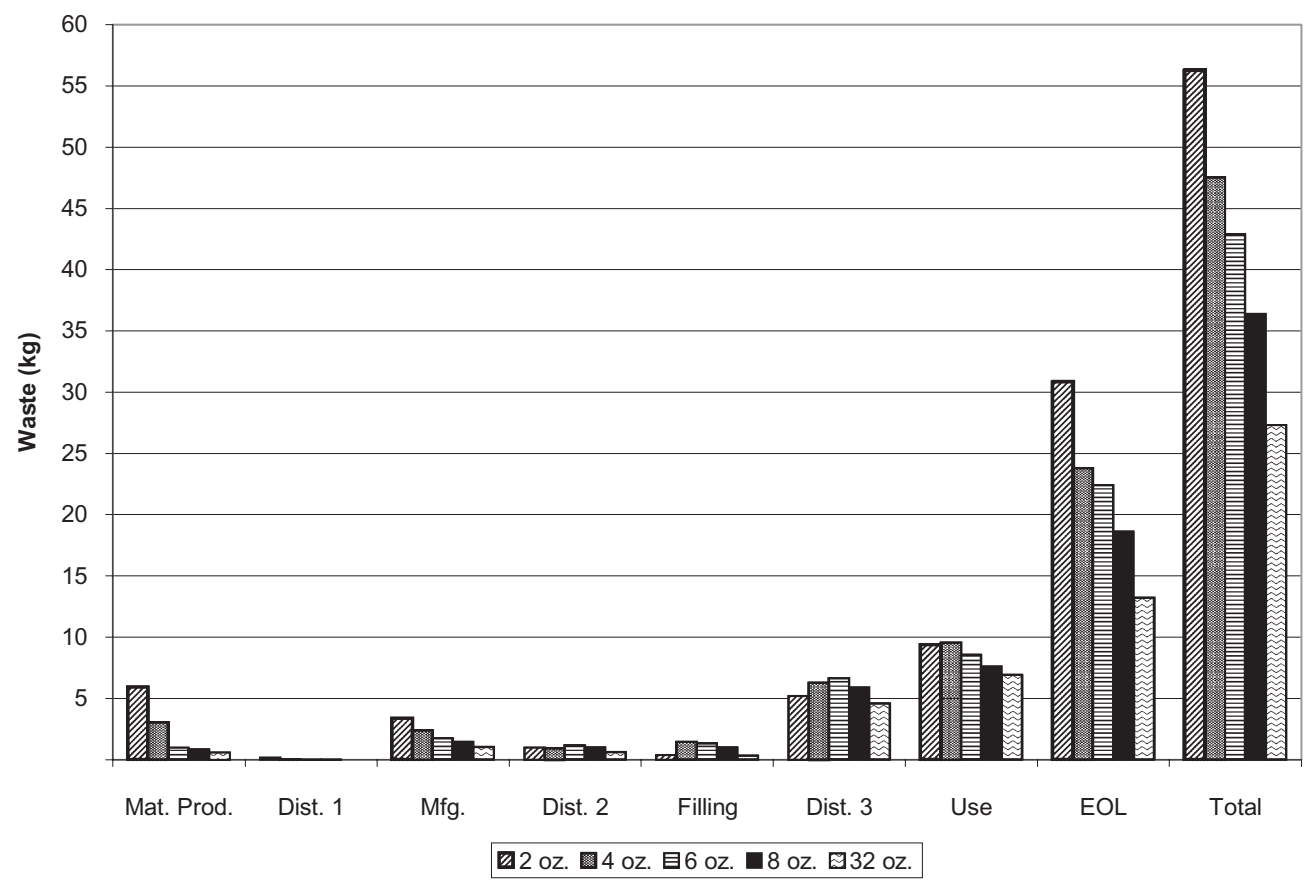

Figure 5. Current PDS life cycle solid waste by phase.

average US rate. While the $15.8 \%$ recycle rate for the wraps and cartons reduced the solid waste of the $2 \mathrm{oz}$ and $4 \mathrm{oz}$ product delivery systems, this reduction did not offset the larger quantity of solid waste of these systems resulting from the greater mass of primary packaging required to deliver $1000 \mathrm{lb}$ of yogurt.

In addition to energy and solid waste, other burdens and impacts were calculated, including air emissions, emissions to water, water use, GWP and ODP. The resulting quantities for each category are presented in Table 8 . Total mass of air pollutant emissions and emissions to water should be interpreted with caution; it is misleading to consider only total mass without understanding the breakdown by specific pollutants due to varying toxicity and human health impacts. The relative distribution of specific air pollutant emissions and water pollutant effluents did not change significantly among container systems. This was attributed to similarities in material composition, transportation modes, and energy use among the PDSs.
Most other categories follow expected patterns; both air emissions and GWP roughly coincide with the energy use profile. Emissions to water decrease as the container sizes increase, due to the larger packages being less material-intensive than smaller sizes and the use of paperboard in the $2 \mathrm{oz}$ and $4 \mathrm{oz}$ product delivery systems, which generates more water-borne pollutants in its production than plastic materials. ODP follows a similar pattern for the same reasons. The one exceptional category is water use. The $32 \mathrm{oz}$ PDS has one of the highest water requirements, due to the consumption phase where bowls must be washed. All the other containers are single serving containers and were assumed to be their own serving dish and therefore do not have this burden.

\section{Suggested improvements}

Environmental performance improvement strategies were investigated by examining the results of the LCA and best practices in packaging across 
and Science

Table 8. Life cycle environmental burdens for current PDS

\begin{tabular}{|c|c|c|c|c|c|c|}
\hline Burden category & Units & $2 o z$ & $4 o z$ & $6 o z$ & $8 o z$ & $32 \mathrm{oz}$ \\
\hline $\begin{array}{l}\left.\text { Air emission (excluding } \mathrm{CO}_{2}\right)^{1} \\
\text { Emissions to water } \\
\text { Water use } \\
\text { Global warming potential }{ }^{2} \\
\text { Ozone depletion potential }\end{array}$ & $\begin{array}{l}\mathrm{g} \\
\mathrm{g} \\
\text { litres } \\
\mathrm{kg} \mathrm{CO} \\
\mathrm{mg} \mathrm{CFC-II}\end{array}$ & $\begin{array}{r}3280 \\
1410 \\
1150 \\
226 \\
8.83\end{array}$ & $\begin{array}{r}3420 \\
1270 \\
3550 \\
256 \\
6.60\end{array}$ & $\begin{array}{c}3440 \\
1200 \\
3080 \\
240 \\
5.05\end{array}$ & $\begin{array}{l}3000 \\
1050 \\
2560 \\
209 \\
4.13\end{array}$ & $\begin{array}{c}2610 \\
899 \\
3590 \\
195 \\
3.05\end{array}$ \\
\hline
\end{tabular}

industries. Each strategy was modelled to quantify the impact on the environmental burdens at each stage of the life cycle. Those that most significantly lowered burdens and were the most practical to implement became the recommended improvement strategies. They include:

- Change the cup manufacturing process from injection-moulding to thermoforming.

- Eliminate the lids on the $6 \mathrm{oz}$ and $8 \mathrm{oz}$ container sizes, leaving just the seal.

- Increase the number of $2 \mathrm{oz}$ tubes per carton from eight to ten.

- Reduce the transport distance for finished product by opening a second facility; this will reduce the average distance by approximately $35 \%$.

- Improve the fuel efficiency of delivery trucks by $10 \%$.

- Upgrade to high efficiency refrigerators in consumers' homes.

- Replace inefficient water heaters at consumers' homes with more efficient, on-demand units.

- Increase the recycling rate of primary packaging at end-of-life from $0 \%$ to $10 \%$ for plastics and from $16 \%$ to $26 \%$ for paperboard.

- Increase the incineration rate of containers at end-of-life from the national average of $23.5 \%$ to $30 \%$.

Table 9 shows the estimated energy reductions associated with each of these improvement strategies. Table 10 shows the solid waste reductions expected. The right-most column in both tables shows a composite PDS, which consists of equal percentages of the five container sizes based on weight of yogurt delivered. The actual sales are not distributed evenly among the container configurations. The 8 and $32 \mathrm{oz}$ sizes represent a majority of sales; however, the smaller sizes are the fastestgrowing segment. The composite PDS is used to show the overall impacts of the improvements and therefore improvements that are made to only a few container sizes have a dampened effect.

\section{Packaging design and manufacturing}

The design of the primary packaging and the manufacturing technique employed can have significant impacts on lowering life cycle energy consumption, solid waste generation and other environmental burdens. The yogurt producer chiefly determines the attributes of their packaging with input from their packaging supplier. While packaging design is constrained by performance, marketing and economic factors, this study revealed that significant gains are still achievable through changes in design and manufacturing methods.

The thermoforming process can achieve thinner cup walls compared to cups manufactured by an injection-moulding process. This results in reductions in the mass of the containers and the associated environmental burdens. Several major yogurt manufacturers currently use thermoformed PP cups and thermoformed polystyrene (PS) cups are used extensively in Europe. The switch to thermoformed cups would reduce energy consumption for the composite PDS by $10 \%$. It would also 
Table 9. Energy reduction results from improvement strategies

\begin{tabular}{|c|c|c|c|c|c|c|c|}
\hline Strategy & Units & $2 o z$ & $4 o z$ & $6 o z$ & $8 \mathrm{oz}$ & $32 \mathrm{oz}$ & Composite' \\
\hline Current PDS & MJ & 4050 & 4670 & 5230 & 4390 & 3620 & 4240 \\
\hline \multicolumn{8}{|l|}{ Packaging design and manufacturing } \\
\hline $\begin{array}{l}\text { Thermoformed cups } \\
\text { Reduction (\%) }\end{array}$ & MJ & & $\begin{array}{r}4360 \\
6.8\end{array}$ & $\begin{array}{r}4 / 20 \\
9.8\end{array}$ & $\begin{array}{r}4110 \\
6.4\end{array}$ & $\begin{array}{l}2950 \\
\quad 18.6\end{array}$ & $\begin{array}{l}3810 \\
10.1\end{array}$ \\
\hline $\begin{array}{l}\text { Eliminate lids ( } 6 \text { and } 8 \mathrm{oz} \text { ) } \\
\text { Reduction }(\%)\end{array}$ & MJ & & & $\begin{array}{l}4190 \\
20.0\end{array}$ & $\begin{array}{l}3610 \\
17.7\end{array}$ & & $\begin{array}{l}3890 \\
8.1\end{array}$ \\
\hline $\begin{array}{l}\text { Increase tubes/carton } \\
\text { Reduction (\%) }\end{array}$ & MJ & $\begin{array}{r}3690 \\
9.0\end{array}$ & & & & & $\begin{array}{r}4200 \\
0.8\end{array}$ \\
\hline \multicolumn{8}{|l|}{ Product distribution } \\
\hline $\begin{array}{l}\text { Reduce transport distance } \\
\text { Reduction (\%) }\end{array}$ & MJ & $\begin{aligned} 3850 & \\
5.1 & \end{aligned}$ & $\begin{array}{r}4470 \\
4.4\end{array}$ & $\begin{array}{r}5030 \\
3.9\end{array}$ & $\begin{array}{l}4190 \\
4.6\end{array}$ & $\begin{array}{r}3430 \\
5.3\end{array}$ & $\begin{array}{l}4040 \\
4.7\end{array}$ \\
\hline $\begin{array}{l}\text { Improve fuel effíciency } \\
\text { Reduction (\%) }\end{array}$ & MJ & $\begin{array}{l}4000 \\
1.3\end{array}$ & $\begin{aligned} 4620 \\
\text { I.I }\end{aligned}$ & 5180 & $\begin{array}{l}4340 \\
1.2\end{array}$ & $\begin{array}{l}3570 \\
\quad 1.4\end{array}$ & 4180 \\
\hline \multicolumn{8}{|l|}{ Consumption } \\
\hline Efficient refrigerator & MJ & 3990 & 4610 & 5170 & 4340 & 3580 & 4180 \\
\hline $\begin{array}{l}\text { Reduction (\%) } \\
\text { Efficient water heater }\end{array}$ & MJ & $4050^{1.6}$ & $4590^{1.4}$ & $\begin{array}{l}1.1 \\
5170\end{array}$ & $\begin{array}{ll}1.2 \\
4350\end{array}$ & $3500^{1.3}$ & $4160^{1.3}$ \\
\hline Reduction (\%) & & 0.0 & 1.8 & I.I & 1.0 & 3.5 & 1.8 \\
\hline Switch to $32 \mathrm{oz}$ & MJ & 3620 & 3620 & 3620 & 3620 & & 3620 \\
\hline Reduction (\%) & & 10.6 & 22.5 & 30.7 & 17.5 & & 14.5 \\
\hline \multicolumn{8}{|l|}{ End of life } \\
\hline Increase Recycling & MJ & 4050 & 4690 & 5240 & 4400 & 3630 & 4250 \\
\hline Reduction (\%) & & 0.0 & -0.3 & -0.3 & -0.3 & -0.3 & -0.3 \\
\hline Increase incineration & MJ & 4010 & 4630 & 5170 & 4340 & 3590 & 4190 \\
\hline Reduction (\%) & & 1.0 & 1.0 & I.I & I.I & 1.0 & 1.1 \\
\hline
\end{tabular}

'The composite PDS consists of equal percentages of the five container sizes based on weight of yogurt delivered.

reduce solid waste by more than $8.8 \%$ and lower life cycle GWP by more than $6.6 \%$.

Eliminating the lids on the 6 and 8 oz cups was selected since these container sizes are sold as single servings and therefore most consumers do not need a lid for resealing. At least one major manufacturer is selling yogurt in $8 \mathrm{oz}$ containers without a rigid lid. The trade-offs for this strategy includes a reduction in the area available for marketing purposes, the possibility of increased secondary packaging requirements, and consumers may be less likely to reuse the containers. The elimination of the lids on the 6 and $8 \mathrm{oz}$ sizes would reduce energy consumption by $8.1 \%$ for the composite PDS. Eliminating the lids would also reduce solid waste by $7.1 \%$.

The third packaging design strategy is to increase the number of $2 \mathrm{oz}$ tubes per carton from eight to 10. This would allow more yogurt to be transported in the same number of cartons, thereby reducing the burdens associated with the production, transportation and disposal of the cardboard used to make the cartons. For this modification in the $2 \mathrm{oz}$ PDS, a $9.0 \%$ energy reduction is possible and the solid waste reduction is nearly $15 \%$.

\section{Distribution strategies}

The energy used to transport the materials throughout the life of the product delivery system accounts for $15 \%$ of the total life cycle energy. The energy consumption is dependent on a variety of factors, including the mode of transport, transport efficiency, transport distance, weight of product and speed. This study examined the effect of improving the efficiency of the trucks by $10 \%$. An improvement of this magnitude is achievable through a number of technological and operational 
and Science

Table 10 . Solid waste reduction results from improvement strategies

\begin{tabular}{|c|c|c|c|c|c|c|c|}
\hline Strategy & Units & $2 o z$ & $4 \mathrm{oz}$ & $6 \mathrm{oz}$ & $8 o z$ & $32 \mathrm{oz}$ & Composite' \\
\hline $\begin{array}{l}\text { Current PDS } \\
\text { Packaging design }\end{array}$ & $\mathrm{kg}$ & 56.2 & 47.5 & 42.8 & 36.4 & 27.3 & 37.5 \\
\hline Thermoformed cups & $\mathrm{kg}$ & & 45.3 & 38.8 & 34.3 & 22.0 & 34.2 \\
\hline Reduction (\%) & & & 4.8 & 9.4 & 5.7 & 19.5 & 8.8 \\
\hline Eliminate lids ( 6 and $8 \mathrm{oz}$ ) & $\mathrm{kg}$ & & & 34.8 & 30.4 & & 34.9 \\
\hline Reduction (\%) & & & & 18.8 & 16.6 & & 7.1 \\
\hline Increase tubes/carton & $\mathrm{kg}$ & 47.8 & & & & & 36.7 \\
\hline Reduction (\%) & & 15.0 & & & & & 2.0 \\
\hline \multicolumn{8}{|l|}{ Distribution } \\
\hline Reduce transport distance & $\mathrm{kg}$ & 55.5 & 46.8 & 42.1 & 35.6 & 26.6 & 36.7 \\
\hline Reduction (\%) & & 1.4 & 1.6 & 1.8 & 2.1 & 2.7 & 2.0 \\
\hline Improve fuel efficiency & $\mathrm{kg}$ & 56.0 & 47.3 & 42.6 & 36.2 & 27.1 & 37.3 \\
\hline Reduction (\%) & & 0.4 & 0.4 & 0.5 & 0.5 & 0.7 & 0.5 \\
\hline \multicolumn{8}{|l|}{ Consumption } \\
\hline Efficient refrigerator & $\mathrm{kg}$ & 53.7 & 45.0 & 40.6 & 34.4 & 25.6 & 35.4 \\
\hline Reduction (\%) & & 4.5 & 5.3 & 5.2 & 5.5 & 6.4 & 5.5 \\
\hline Efficient water heater & $\mathrm{kg}$ & 56.2 & 47.5 & 42.8 & 36.4 & 27.2 & 37.4 \\
\hline Reduction (\%) & & 0.0 & 0.1 & 0.1 & 0.1 & 0.4 & 0.2 \\
\hline Switch to $32 \mathrm{oz}$ & $\mathrm{kg}$ & 27.3 & 27.3 & 27.3 & 27.3 & & 27.3 \\
\hline Reduction (\%) & & 51.4 & 42.6 & 36.3 & 25.0 & & 27.2 \\
\hline \multicolumn{8}{|l|}{ End of Life } \\
\hline Increase recycling & $\mathrm{kg}$ & 56.2 & 45.1 & 41.4 & 35.1 & 26.3 & 36.2 \\
\hline Reduction (\%) & & 0.0 & 5.2 & 3.4 & 3.5 & 3.7 & 3.4 \\
\hline Increase incineration & $\mathrm{kg}$ & 53.1 & 44.9 & 40.1 & 34.1 & 25.7 & 35.3 \\
\hline Reduction (\%) & & 5.6 & 5.6 & 6.3 & 6.2 & 5.8 & 5.9 \\
\hline
\end{tabular}

changes, such as enhancing the efficiency of the delivery vehicles' powertrain, reducing vehicle load (e.g. improving aerodynamics and reducing rolling resistance), and reducing driving speeds and idling time. The $10 \%$ improvement in truck fuel efficiency resulted in a $1.5 \%$ reduction in energy use and a $5.2 \%$ reduction in global warming potential.

A second distribution strategy involved reducing the distance between the yogurt manufacturer and the retailers and distributor by $35 \%$. Stonyfield Farm is located on the East Coast and distributes yogurt to the entire country from that location. It was calculated that the distance the yogurt is transported could be reduced by approximately $35 \%$ if a second facility was opened on the West Coast and distributors were serviced from the facility nearest to them. The reduction in yogurt transport distance resulted in a reduction in life cycle energy consumption of $4.7 \%$ and a reduction in GWP of $10 \%$.

\section{Consumer options}

The consumption phase modelled for this study goes far beyond merely eating the yogurt. The yogurt must be refrigerated in the consumers' home and spoons and bowls used during the consumption process must be washed. The consumer is also responsible for choosing the container size in which to purchase the yogurt. The results of applying consumer strategies are included to indicate the power of consumer choices in affecting the life cycle burdens of the product delivery system.

Energy efficiency of refrigerators has improved significantly over the past 15 years. In 1987, the typical refrigerator used $0.137 \mathrm{kWh} / \mathrm{ft}^{3} /$ day while the average energy efficiency for a refrigerator manufactured after 1995 was $0.0893 \mathrm{kWh} / \mathrm{ft}^{3} /$ day. A survey of currently available refrigerators showed that the most efficient, widely available models use only $0.054 \mathrm{kWh} / \mathrm{ft}^{3} /$ day. ${ }^{20}$ The use of 
more efficient refrigerators reduced total life cycle energy by $1.3 \%$ and reduced GWP by $6.9 \%$.

Moving to a more efficient water heater has a smaller impact than refrigeration. The energy saving is only $1.8 \%$ for the composite PDS, since the dishwashing needs for consuming yogurt are fairly small. It was assumed that only the $32 \mathrm{oz}$ containers required bowls, while other sizes needed only spoons, except the $2 \mathrm{oz}$ tubes that need neither.

The most powerful choice consumers can make is deciding which size containers to purchase. If all yogurt was bought in $32 \mathrm{oz}$ containers, the life cycle energy could be reduced by nearly $18 \%$ and solid waste could be cut by over $35 \%$.

\section{End-of-life management options}

The final category for improvement strategies involves ways to manage the end-of-life phase better. With current technologies and regulations, the three options for single-use yogurt containers at the end-of-life stage are disposal in a landfill, incineration and recycling. Recycling represents the best option for retaining the embodied energy in the packaging, but this usually entails downcycling, since the use of recycled plastic materials for food contact applications is currently very limited, due to concerns about the potential migration of contaminants into the food. Despite this fact, the two strategies investigated for the end-oflife stage included increasing the recycling rate and increasing incineration.

Increasing recycling from $0 \%$ to $10 \%$ for plastics and from $16 \%$ to $26 \%$ for paperboard has an expected reduction in solid waste $(3.4 \%)$ but a somewhat counter-intuitive impact on energy use. Since recycling removes high-energy plastic materials from the waste stream, fewer energy credits are available from electricity generated by incineration. The reduction in the end-of-life energy credit results in life cycle energy increasing by $0.3 \%$.

The other strategy of increasing the incineration rate can reduce both the life cycle energy use and solid waste generation. By burning the plastics and paperboard in electricity-generating facilities or using them to fuel a cement kiln, productive use is made of the embodied energy instead of simply burying it in a landfill. A $6.5 \%$ increase in incine- ration to $30 \%$ results in a $1.1 \%$ reduction in energy use and a $5.9 \%$ reduction in life cycle solid waste. However, the energy derived from burning waste does increase the life cycle air emissions and GWP by $0.6 \%$ and $3.9 \%$, respectively.

\section{CONCLUSIONS}

This research used life cycle assessment modelling to evaluate the environmental performance of a national brand yogurt producer's product delivery system. This approach was used to highlight the environmental improvement opportunities that are often overlooked when investigations are too narrowly focused on a single aspect or single life cycle phase of a product's packaging. The environmental profile of the current PDS was assessed, which served as a baseline for investigating environmental improvement strategies.

The LCA results indicated that environmental burdens are inversely related to container size when the packaging configuration consists of a cup, seal and lid. Accordingly, the $32 \mathrm{oz}$ yogurt cups proved to be the best choice in every category among the $6 \mathrm{oz}, 8 \mathrm{oz}$ and $32 \mathrm{oz}$ containers. Consumers purchasing yogurt in $32 \mathrm{oz}$ vs. $6 \mathrm{oz}$ containers can reduce the life cycle energy consumption by $15 \%$ and the life cycle solid waste by $27 \%$. The $2 \mathrm{oz}$ tubes and $4 \mathrm{oz}$ containers did not always fit the same 'bigger is better' pattern. In particular, the multi-packs outperformed the $6 \mathrm{oz}$ in life cycle energy requirements, renewable energy and emissions to air. However, the solid waste produced, water used, and ODP from the 2 oz tube PDS and $4 \mathrm{oz}$ container PDS were by far the highest.

Interpretation of the results identified the segments of the PDS responsible for the largest environmental burdens and these segments were then targeted as areas for improvement. These segments are: distribution from the yogurt producer to distributors and retailers; material production of the primary packaging; and manufacturing of the yogurt containers. The improvement strategies targeting these areas revealed notable opportunities through packaging design, distribution networks, consumer choices and end-of-life management. The greatest improvements can be achieved through packaging design and manufacturing. 


\section{and Science}

Shifting from injection-moulding to thermoforming of the $32 \mathrm{oz}$ container reduces the life cycle energy and solid waste by $19 \%$ and $20 \%$, respectively. Elimination of lids for $6 \mathrm{oz}$ and $8 \mathrm{oz}$ containers also significantly reduces environmental burdens. Life cycle energy was reduced by $20 \%$ and $18 \%$ for the $6 \mathrm{oz}$ and $8 \mathrm{oz}$ containers and life cycle solid waste decreased by $19 \%$ and $17 \%$, respectively. Simply increasing the number of $2 \mathrm{oz}$ tubes per carton from eight to 10 reduced life cycle energy by $9.0 \%$ and life cycle solid waste by $15 \%$ for that PDS. The addition of another distribution site on the West Coast also provided benefits in energy minimization. This study demonstrated the savings that could be achieved by consumers through home improvements, such as more efficient refrigerators for yogurt storage and more efficient water heaters for washing dishes and utensils. While these benefits were less significant than packaging design changes, appliance upgrades would show tremendous benefits if the storage of other food items and other uses of hot water were considered.

The often-overlooked significance of secondary packaging relative to the yogurt containers was highlighted. Secondary packaging production accounted for $55 \%$ of the primary energy consumed in distribution 3 (yogurt filling facility to retailer), compared to $40 \%$ for the energy to transport the yogurt itself.

The systematic life cycle analysis revealed complex interactions and linkages between the components of the yogurt PDS. For example, the light-weighting of corrugated boxes (secondary packaging) could actually result in increased environmental burdens. This could result from the need to increase the weight of the energy-intensive primary packaging to compensate for a decrease in the structural performance of the boxes. Life cycle modelling techniques should enable packaging designers to find an optimum relationship.

As a general recommendation for future environmental research, the authors emphasize that it would be imprudent to focus on only one segment of the product delivery system in efforts to reduce specific environmental burdens. It is important not to limit the boundaries of analysis to a particular packaging technology or specific environmental impact category. The LCA approach, which takes into consideration the product delivery system as a whole, will be a more reliable and comprehen- sive tool to improve environmental performance through packaging technology choices. This approach enables the analysis of environment tradeoffs (e.g. energy vs. solid waste) among alternative improvement strategies.

The results of this study were submitted to Stonyfield Farm in April 2001 and, since that time, Stonyfield Farm has implemented several of the suggested improvement strategies. In January 2003, Stonyfield Farm replaced the plastic lids and plastic inner seal for the $6 \mathrm{oz}$ and $8 \mathrm{oz}$ containers with a foil seal. In 2003, Stonyfield Farm also began investigating the use of cups manufactured using a thermoforming process. A switch from injectionmoulded cups to thermoformed cups would significantly reduce the mass of the primary packaging. Stonyfield Farm uses its website to provide its consumers with tips on improving energy efficiency of home appliances such as refrigerators, dishwashers and hot water heaters.

\section{ACKNOWLEDGEMENTS}

This research was funded through a grant from Stonyfield Farm Inc. and Polytainers Inc. Nancy Hirshberg of Stonyfield Farm and Stephen Robert of Polytainers were instrumental throughout all phases of this project.

\section{REFERENCES}

1. US EPA Municipal Solid Waste in the United States: 1999 Final Report: http://www.epa.gov/ epaoswer/non-hw/muncpl/msw99.htm (accessed 14 January, 2002).

2. International Organization for Standardization. Environmental Management - Life Cycle AssessmentPrinciples and Framework. ISO 14040:1997(E), Geneva, 15 June 1997.

3. Vigon BW, Tolle DA, Cornaby BW et al. Life-cycle Assessment: Inventory Guidelines and Principles. EPA/600/R-92/245. U.S. EPA, Risk Reduction Engineering Laboratory, 1993.

4. Society of Environmental Toxicology and Chemistry. A Technical Framework for Life-Cycle Assessment, Fava J, Denison R, Curran B et al. (eds). Society of Environmental Toxicology and Chemistry: Pensacola, FL, 1994; 134.

5. Swiss FOEFL. Ecobalance of Packaging Materials: State of 1990. Swiss Agency of Environment, Forests and Landscape: Berne, Switzerland, 1991. 
6. Swiss Agency for the Environment, Forests and Landscape. Life Cycle Inventory of Packagings. Swiss Agency for the Environment, Forests and Landscape: Berne, Switzerland, 1998.

7. Franklin Associates. Resource and Environmental Profile Analysis of High-density Polyethylene and Bleached Paperboard Gable Milk Containers, Franklin Associates Ltd: Prairie Village, KS, 1991.

8. Mekel OCL, Huppes G. Environmental effects of different package systems for fresh milk. Center for Environmental Studies. Leiden University CML Report 1990; 70.

9. Rydberg T, Frankenhaeuser M, Lundahl L et al. Chalmers Industriteknik CIT-Ekologik Report, 1995; 3.

10. Keoleian GA, Spitzley DV. Guidance for improving life-cycle design and management of milk packaging. J. Indust. Ecol. 1999; 3: 111-125.

11. Lundholm MP, Sundstrom G. Tetra Brik Aseptic Environmental Profile: Resource and Environmental Impact of Tetra Brik Aseptic Carton and of Refillable Glass Bottles. Tetra Pak: Malmo, Sweden, 1985; 173 pp.

12. Franklin Associates. Comparative Energy and Environmental Impacts for Soft Drink Delivery Systems. Franklin Associates Ltd: Prairie Village, KS, 1989.

13. Produkt-Ökobilanz vakuumverpackter Röstkaffee (in German, with a 'Standard Report Form for LCA Studies' in English) (Vacuum Packed Roasted Coffee) Commissioner: Kraft Jacobs Suchard Company Practitioner: Fraunhofer Institut für Verfahrenstechnik und Verpackung, Giggenhauserstr. 35, D-85354 Freising, Germany.
14. Andersson K, Ohlsson T, Olsson P. Screening life cycle assesment (LCA) of tomato ketchup: a case study. J. Cleaner Production 1998; 6(3-4): 277288.

15. Brachfeld D, Dritz T, Kodama S, Phipps A, Steiner E. Life cycle assessment of the Stonyfield Farm product delivery system. Report No. CSS01-03. Center for Sustainable Systems: Ann Arbor, MI, 2001; 356 pp.

16. DEAM (Data for Environmental Analysis and Management) is a database used by TEAM (Tools for Environmental Analysis and Management), Version 3.0, Paris, France, 1999. www.ecobilan.com

17. Characterization of Municipal Solid Waste in the United States: 1998 Update P13 Table ES-1 Generation, Materials Recovery, Composting, Combustion, and Discards of Municipal Solid Waste, 1960-1997. US EPA, Office of Solid Waste Report No. EPA530, July, 1999.

18. International Panel on Climate Change (IPCC). Climate Change 1995: The Science of Climate Change, Houghton JT, Meira Filho LG, Callender BA et al. (eds). Cambridge University Press: Cambridge, 1996; pp 572.

19. World Meteorological Organization. Scientific Assessment of Ozone Depletion, 1991. Global Ozone Research and Monitoring Project Report No. 25. AREP/ENV: Geneva, 1992.

20. Department of Energy-Energy Information Administration. Efficiency of an Average New Refrigerator in the United States. http://www.eia. doe.gov/emeu/25opec/sld026.htm 